\title{
Integrating Gender into Disaster Management in Indonesia
}

\author{
Asima Yanty Siahaan, Februaty Tambunan \\ University of Sumatera Utara, Medan \\ Faculty of Social and Political Sciences \\ Department of Public Administration, FISIP USU, Medan \\ Email: asimayantysiahaan@gmail.com
}

\begin{abstract}
The strategic role and responsibility of local government in protecting the community from vulnerability and in reducing disaster impacts have been increasingly acknowledged in disaster policy in Indonesia.This article explores factors contributed to the ignorance of gendermainstreaming in North Sumatra province. It focuses on the capability of local government in integrating gender in disaster management. This study is based on qualitative research design. Review of policies on disaster management is aimed to identify whether the policies have integrated gender or not. Field study is aimed to assess the implementation of disaster management policies, identify the obstacles from gender perspective, the reasons for gender integration, and policy impact on social and economic aspects. Data were analysed using qualitative content analysis in particular to explore how local government response todisaster. The findings demonstrate the role and capability of local government in integrating gender in disaster management is still limited due to the lack of knowledge on gender and gender mainstreaming in disaster, lack of commitment, the lack of sex disaggregated data and lack of coordination with women's empowerment and gender equity local institutions. This study suggests the enforcement of the establishment of gender focal point within disaster management and capacity building of knowledge toward commitment is of great significant in enhancing local government capability in integrating gender in disaster management.
\end{abstract}

Keywords: Disaster Management, Gender Integration, Local Government.

\section{INTRODUCTION}

\section{Gender Issues in Disaster Management}

Individual and institutions play
important role in determining how communities will be influenced by disaster and the following impacts of disaster. Studies have revealed that community's structure which marginalized women as the result of patriarchal structure and institution as well as gender bias government policies have increased the vulnerability of women in disaster (Iqbal et.al., 2013; Sarah, 2015; Ashraf et.als., 2015). In Bangladesh women who live in coastal areas experience more vulnerability after the occurrence of disaster due to their social economic status which is lower than men and therefore their needs and acitivites in earning their livelihoods are ignored in disaster planning and management (Ashraf et.al., 2015).

Women's vunerabilty resulted from their previous subordination before and after disaster is the root of women's vulnerability in disaster. In the study of women and disaster in Sri Lanka, women's vulnerability did not only related to economy or their livelihoods but also issue of violence frequently emerge (Banford et.al., 2015). Besides women's subordination, men's domination and the role of women in providing services to their family and households and their perceived domestic roles are also significant factors which cause women's vulnerability in facing disaster (ILO, 2013).

On the other hand, studies also demonstrate that women actively engage in disaster management (Alston and Saleem, 2013; UNISDR, 2012). Women have crucial social knowledge and capacity which are yet to be utilized in reducing the risk and impact of disaster (Greet, 1994). Besides their role as the main provider of food and emotional comfort in family, women's skill in adapting to disaster, 
close and extensive network with other women and women's knowledge on natural resources and eco system are strategic instrument in dealing and managing disaster. However women are frequently 'disappear' or ignored in the whole of disaster management programs and their capacities have been left untapped and utilized in disaster policy, planning, strategy and implementation (UNISDR 2014; Iqbal 2013).

The frequent occurences of natural disasters in Indonesia has caused extensive loss and disruptions to people living and working in hazardous environments. The gendered impacts of these extreme natural disasters unfold in varying geographic, socioeconomic, political, social, and cultural contexts. Survey on the impact of Tsunami in Aceh, India and Srilanka reveal that $80 \%$ of the victims of Tsunami are women (Oxfam 2005; Abeysekera 2006). Widow, single women and women with low income and members of culturally and ethnically marginalized community were among the majority of the deceased Tsunami victims. The case of disaster in Bantul highlights similar result in which women were the most vulnerable group in which $60 \%$ of those who were deceased and heavily injured were women (Yumarni, 2015). During the early stage of disaster, women found difficulty in accessing facilities related to their reproductive health (Komnas Perempuan, 2012). Women had to work harder to fulfill their household needs especially water and food which then create another poverty and vulnerability cycle. This is due to women's more limited acces and participation to income, education and decision making during the breakdown of facilities caused by disaster.

Gendered disaster impacts are not only influenced by biological differences between men and women, rather it has been more severely determined by imbalance and gendered biases of politics, social economy and culture in many countries in Asia which increase women's vulnerability on the impacts of disaster (HFA, 2014; Ariyabandu, 2009; United Nations, 2009). Ignorance to gender based needs in disaster management frequently strengthen the gaps and discrimination to women in the form of gap in access in gaining assistance and service facilities (Inter-Agency Standing Committee, 2010; UN/ADPC, 2010).

Realizing the gendered impact of disaster and the urgency of implementing a gender sensitive disaster management and prompted by the adoption of Hyogo Framework for Action and Seandai Framework, the head of Indonesia National Disaster Management Agency has recently issued regulation on Gender Mainstreaming in Disaster Management (Perka No.13 Year 2014). This regulation obligates that disaster management in Indonesia should be implemented based on gender responsivity to ensure the just and humane fulfillment of women's and men's needs in disaster.Gender mainstreaming in disaster management should utilize gender sensitive indicators in access, participation, and control in resources, decision making and benefits.

North Sumatra province is categorized by national government as one of the province with disaster vulnerable areas/ regions. Since 2010 the provincial Disaster Management Agency (DMA/BPBD) has been established to ensure the effective and coordinated disaster management. Differ with the achievement of local government of Bantul which has institutional capabilty and policies on human resources and finance has been successful in enhancing gender equity in disaster management which then enhance community's resilient toards disaster (Yumarni, 2015). However, gender mainstreaming as reflected in the processes and approaches in managing disaster in this region is still ignored.

Study of the implementation of gender mainstreaming in disaster management in Indonesia is still limited. The existing literature on gender mainstreaming in disaster is mostly based on cases in Java (Yumarni, 2015; Prabandari and Nandyatama, 2010). Yumarni (2015) focusing on the capability of local government conduct research on gender mainstreaming in disaster management in 
Bantul. Prabandari dan Nandyatama (2010) study on women's participation in Merapi eruption disaster and research on women's refugees live strategies.

This study examines the implementation of gender mainstreaming in disaster management in North Sumatra province so that gender based discrimination in disaster management can be avoided and the needs and participation of diverse groups in community may be acknowledged and integrated in disaster management policy and strategy in pursuing gender equity and fairness in disaster management in Indonesia as mandated in Law No.24 Year 2007 on Disaster Management and Perka BNPB No.13 year 2014 on Gender Maintreaming in Disaster Management.

\section{A. RETHORICS IN DISASTER MANAGEMENT POLICY}

Hyogo Framework for Action and Seandai Framework have long persistently argued that gender perspective should be integrated in disaster risk reduction and management including the early assessment, early warning system, education and training on disaster (UNISDR, 2012). Although some countries have policies, regulations and institutions to enhance gender equity in various sectors of development, governments have been slow in gender mainstreaming especially in disaster risk management. Up to 2011 only $20 \%$ of the countries have reported progress in integrating HFA in their action plan (UNISDR, 2014). Women labelling in vulnerable category has excluded women from decision making and resulted in the disappearance of women's contribution in building community resilient at the grassroots. HFA2 which also known as the Sendai Framework for Disaster Risk Reduction (Sendai Framework) report highlights the low understanding on gender in disaster risk reduction and management.

Gender rethorics on disster risk reduction and management continues with the conceptualization of disaster as outside development discourse has created negative impact on recognition and the realization of women's rights in disaster management (Sarah,
2015). Policy rethorics in disaster management place women as service providers in disaster which then create the feminization of obligation and responsibility in disaster management (Bradshaw, 2010; Chant, 2008; Molyneux, 2006). Therefore, the involvement of women in disaster has focused more on the efficiency aspect which is in line with 'Women in Development' approach which perceive women's involvement as merely wise economic action since it reduce the cost of disaster management rather than to enhance women's welfare and the fulfillment of women's rights in disaster (Bradshaw et.al., 2013).

\section{B. GENDER MAINSTREAMING IN DISASTER MANAGEMENT}

Gender mainstreaming is "the process of assessing the implications for women and men of any planned action, including legislation, policies or programmes, in any area and at all levels. It is a strategy for making the concerns and experiences of women as well as men an integral part of the design, implementation, monitoring and evaluation of policies and programmes in all political, economic and societal spheres, so that women and men benefit equally and inequality is not perpetuated. The ultimate goal of mainstreaming is to achieve gender equality." (UN/ECOSOC, 1997). This definition views gender mainstreaming as an instrument to increase women's role in development where gender inequity occurs and to integrate women's value in development in order to pursue gender equity.

The United Nations Office for Disaster Risk Reduction (UN/ISDR, 2002) identifies gender mainstreaming as a way to integrate gender perspective in disaster risk reduction. Gender mainstreaming is defined as "fostering awareness about gender equity and equality etc., to help reduce the impact of disasters, and to incorporate gender analysis in disaster management, risk reduction and sustainable development, to decrease vulnerability" (Interagency Secretariat for the UN/ISDR, 2002, p.3). Thus, gender mainstereaming is a process which can be used to integrate women's perpective in disaster risk reduction and 
management. It also includes gender analysis which identifies gender inequality between women and men in relation to their rights, opportunities to develop themselves and access to resources in disaster management as part of gender mainstreaming process.

Gender mainstreaming is a strategy which integrate both men's and women's needs and experiences as an integrated dimension in design, implementation, monitoring and evaluation of policies and programs so that gender inequity will not be escalated through processes in disaster management (Enarson and Chakrabarti, 2009). Hence, gender mainstreaming in disaster management includes integration of gender sensitive strategies and initiatives in disaster management processes which aims at fulfilling the practical and strategic needs of women and men.

Practically, gender mainstreaming in disaster management also includes the availability of gender based data and statistics on the impact of disaster, studies on gender based vulnerabilities, risk and capacity, analysis on men's and women's needs, gender sensitive policy and the participation of men and women in the whole stages and processes of disaster management.

In line with global commitment and Beijing Declaration on pursuing gender equity, the government of Indonesia has issued Presidential Instruction No.9 Year 2000 on Gender Mainstreaming. In its implementation, this policy obligates the integration gender mainstreaming in all process of national development. Law No.24 Year 2007 on Disaster Management has attempted to integrate gender in disaster management. The law stipulates that gender is the basis, principle and the goal of disaster management law together with other principles of humanity, equity in law and government, harmony, order, law enforcement and togetherness. Although gender mainstreaming has been integrated in Law No. 24 Year 2007 on Disaster Management, gender mainstreaming is described and regulated in detail in Perka No.13Year 2014 on Gender Mainstreaming in Disaster Management. This gender mainstreaming is a strategy to specifically integrate gender into an integrated dimension of planning, implementation, monitoring and evaluation of disaster management policy, programs and activities.

Local government's capability in managing disaster and in building local community's resilient toward disaster including in integrating gender in gender mainstreaming in disaster management and inhancing local community's resilience in disaster is crucial (UN/ISDR, 2012). Local government capability includes leadership and strong government's commitment to gender mainstreaming, institutional capacity to ensure women's representation, the availability of gender analysis by utilizing gender sensitive data, gender experts who understand gender policy desing in disaster management context and policies and program design related to disaster risk reduction and resilience (Moser, 2005; Yumarni, 2015).

\section{METHODOLOGY}

This study is based on qualitative research design. Data were analysed using qualitative content analysis in particular to explore how localgovernment response to earthquake disaster.Review of policies on disaster management is aimed to identify whether the policies haveintegrated gender or not. Field study is aimed to assess the implementation of disastermanagement policies, identify the obstacles from gender perspective, the reasons for genderintegration, and policy impact on social, economic and psychological aspects.In depth interviews were conducted with informants involved in disaster management in North Sumatra province, Medan city and Karo regency which consists of head and secretary of BPBD, Social and Employment agencies, Women Empowerment and Family Planning Board, head of disaster impacted villages, gender focal point, faithbased organizations, Indonesian Red Cross (PMI), and disaster survivors. 


\section{RESULTS AND DISCUSSION}

\section{A. Gap Between Disaster Management Policy and Gendermainstreaming Policy in Indonesia.}

Law No. 24 Year 2007 on Disaster Management has mandated local government as the corrdinator and implementer in disaster managemenet in Indonesia. Autonomous role bestowed upon local government in managing disaster is based on the argument that local government is responsible to protect and to realize welfare to their local communities. More active role and responsilbitly of local government is also mandated by law in ensuring that disaster management is integrated in local development programs incuding funding allocation for disaster amangement. The frequent occurences of disasters in Indonesia requires the integration of disaster perspective into development policies, planning and programs. Disasters disrupts development, therefore local government should have capability in disaster management.

Structurally, BPBD Provinsi dan BPBD Kabupaten/Kota is under and accountable to the head of local government. The tasks, functions and responsibility of BPBD include all aspect of disaster management starting from pe-disaster to post disaster stages. BPBD also conduct disaster emergency response, rehabilitation and reconstruction.The conceptual, mangeral and technical organizational structure of BPBD is determined uniformly throughout Indonesia.

Law no.27 Year 2007 serves as the basis for the establishment of disaster management system and institutions in Indonesia. Although based on this law disaster management perspective should be integrated in development planning in Indonesia, yet, it has not explicitly regulates gender mainstreaming in disaster management.

Prior to the issuance of law on disaster management in Indonesia, the government of Indonesia has issued Inpres no.9/2000 on Gender mainstreaming which provides general legal basis in implementing gender mainstreaming in development processes in Indonesia. This policy is followed by the issuance of Permendagri No. 15 Year 2008 which then revised by Permendagri No.7 Year 2011 which provides guidelines in implementing gender mainstreaming.

However, the implementation of various government's policies and regulations in gender mainsteaming has been slow. To encourage and foster the follow up of gender mainstreaming, Indonesian government issued Common letters agreed by four ministries which obligates all government's institutions and units to implement gender mainstreaming in accordance with their functions and roles whether in the form of activities and in gender responsive budgeting.

These gender mainstreaming policies have been implemented by local government in Karo, Medan and North Sumatra by establishing women's empowerment and family agencies.Furthermore, North Sumatra provincial government has translated this policy No.9 Year 2000 on Gender mainstreaming into various policies in order to operationalize it in governance and development in North Sumatra. This national policy on Gender Mainstreaming has been translated into various local government regulations and decrees such as governor decision on Gender Mainstreaming Task force in North Sumatra, Gender based Data Forum, Responsive Gender Planning and Budgeting.

Although the available laws and policies on gender mainstreaming in Indonesia provide basis for local government and other stakeholders involve in disaster management in realizing gender sensitivity and responsitivity in disaster management, yet policy which explicitly provides guideline in implementing gender mainstreaming is just recently regulated in Perka BNPB No.13 Year 2014 on Gendermainstreaming in Disaster Management . Referring to Inpres no.9 Tahun 2000, this gender mainstreamging in disaster management policy defines gender mainstreaming as a strategy which to integrate gender into an integrated dimension of planning, implementation, monitoring and evaluation of national development. The goal of 
gender mainstreaming is to ensure equal and humane fulfillment of men's and women's needs in implementing a gender equal and responsive disaster management.

Local government officials' knowledge and understanding on gender mainstreaming in disaster management are very limited compare to their understanding on law on Disaster management. While during the interviews local government officials described and explained various aspects of disaster management law, most of them are unfamiliar with Perka BNPB on Gender mainstreaming in Disaster Management. Only one informant had read this Perka BNPB on Gender mainstreaming in Disaster Management and some of them even with high rank and decision making position in local government's disaster management agencies have not yet heard about the issuance of this regulation. Even the official who have read this regulation consider that the implementation of this regulation is perceived as 'abnormal', not yet applicable due to the 'abnormality' of the condition caused by disaster (Interview. BPBD Karo regency. August 2016).

Based on analysis of law on disaster, 'gender' disappeared in the formulation and arrangement of disaster management. North Sumatra local government's regulation No 8 Year 2013 on Regional Disaster Management use the term 'vulnerable group' rather than gender mainstreaming and include women in this group category. This term reveals local government lack of understanding on gender mainstreaming since it views women merely as victims. Women disappeared in this regulation since in law on gender mainstreaming those who are categorized as vulnerable are children, elderly, and disable. Women are also placed as community in general. Consequently, women's specific needs were unrecognized and enourage the delivarence of assistance without considering speicif needs of women in disaster.

\section{B. The 'Tyrany of the Urgent': Justification for the Ignorance of Gender Mainstreaming in Disaster Management.}

The emergent and urgency of disaster were frequently used to justify the ignorance of gender mainstreaming in all research sites in North Sumatra. Most informants argued that in the midst of the severity of the impact of disaster and considering not only women are victims of disaster, the communal approach has been most appropriate in serving the needs of all community members affected by disasters. In Karo regency refugee camps, rooms for women and children, especially for women with infant were unavailable. Refugees live in camps together as a family. Each family is given a site in refugee camp. The boundary between each family is only marked with boxes or other goods they own. The site for each family is separated by boxes. In refugee's camp at Simpang Enam which is supervised and organized by GBKP, toilets for men and women are available. However, as admitted by a local government official in BPBD Karo, disaster management in general still use the communal approach which is yet to be implemented based on gender sensitivity and responsivity.

\section{Questioning Local Government Commitment to Gendermainstreaming in Disaster Management.}

The establishment of gender focal point has been argued as strategic in ensuring the achievement of gender mainstreaming Considering the complexity of organizational, cultural and structural challenges in realizing gender equity, Indonesia government through Inpres No.9 Year 2000 determined gender focal point as the spearhead in gender mainstreaming in each working units of government's institutions. The task of gender focal point based on Perka BNPB includes promoting and facilitating gender mainstreaming, dissemination of disaster related information and advocacy in disaster management, encouraging the realization of gender responsive planning and budgeting, arranging gender profile in disaster management, formulating policy recommendation, monitoring the implementation of gender mainstreaming in disaster management. 
Almost all local government units in regions in North Sumatra have established gender focal point. To strengthen the position of gender focal point in gender mainstreaming, the head of local government working unit is appointed as the head of gender focal point. However, in general gender focal points experience challenges and obstructions: structurally, culturally and financially. Even after its establishment, gender focal points are ignored and thus unable to influence and advocate planning and local governance (Interview BPPKB North Sumatra province; BPPKB Karo regency, PPKB Medan. 2016). Even the Women's Empowerment and family planning at the provincial level which is the coordinator in mobilizing gender mainstreaming in all local government's working units in North Sumatra, received very little support from local government. Gender focal points experience challenges: financial constarints, human resources especialy limited gender experts and continuing policies and regulations of local government. Despite the stated significant role of Gender focal point in gender mainstreaming, it has been largely undermined by other units in local government which rarely coordinate with gender focal point in implementing development policies including disaster management. Hence, gender focal points in North Sumatra are yet to function and contribute optimally to engendering disaster management due to these intertwined these obstructions.

Local government's official limited understanding and misperception significantly contributes to the ignorance of gender focal point and create challenges to this gender focal point. Gender mainstreaming has been perceived by other local government units as increasing new budget thus create competition over resources between diverse units in local government. In fact, gender mainstreaming does not mean increasing new budget allocation rather it analyzes diverse needs to be adapted and integrated in the overall local government budget.

Local government officials understanding on gender still diverse and they do not fully understand the basic concepts of gender. Most of local governments equates gender as woman and yet to understand the importance of gender mainstreaming to the overall achievement of disaster management. The established gender focal poinst are rarely interacts with other units or departments in the disaster management agency (DMA).

Local government commitment in implementing gender mainstreaming in disaster management is still low. Although Perka BNPB obligates and regulates the establishment of gender focal points di Disaster Management Agency (DMA/BPBD/BPBN), North Sumatra provincial government is the only DMA which has established gender focal point. Up to the time research was conducted, DMA at Karo regency and Medan municipality were yet to establish their gender focal point.

However, the established gender focal point at North Sumatra provincial DMA is yet to be strengthened through capacity of its human resources. The establishment of gender focal point at North Sumatra provincial DMA has been more the result of national mandate which requires local government to establish gender focal point units in DMA. Gender focal point has been established in North Sumatra DMA since 2011 with the head of DMA as the head of gender focal point. Members of gender focal point were appointed by the head of DMA. However, since its establishment gender focal point has been left dormantwith no activity. The only activity of gender focal point was training on gender segregated data which was conducted once in 2011. Based on the evaluation of DMA achievement, the activity related to gender mainstreaming conducted by this provincial DMA was activity on the enhancement of life quality of women victims of disaster which was attended by 120 participants. Interestingly, one of the member of DMA explains that up to now she has not get her official appointment letter as member of gender focal point and the head of DMA did not know the existence of this official letter in DMA (Interview.DMA North Sumatra. September 2016). During 2013 to 2015 gender focal point was in vacuum with no activity. Moreover, members of gender focal point had never been invited to participate in DMA meetings. Lack of 
understanding on gender mainstreaming and gender focal point is also obvious with the frequent changes of officials in attending geder related training and the result of training has never been disseminated. As the head of gender vocal point, the head of DMA appoint officials who attended gender related training without coordination with other gender focal point staff members. In fact, DMA staff who was appointed by the head of gender focal point was not the member of gender focal point. This reflects local government ignorance and understanding of the purpose of gender focal point and the urgency of gender mainstreaming in disaster management which obstructed gender focal point in carrying out their task and realize their goal in gender mainstreaming

\section{CONCLUSION}

The intertwined of structural, cultural and financial obstructions significantly influence the effectiveness of the implementation of various gendermainstreaming disaster management policies in North Sumatra province, Karo regency and Medan municipality in Indonesia. The role and capability of local government in integrating gender in disaster management is still limited due to the lack of knowledge on gender and gender mainstreaming in disaster, lack of commitment, the lack of sex disaggregated data and lack of coordination with women's empowerment and gender equity local institutions.

Although there have been various national, regional and local policy and regulations on gendermainstreaming in Indonesia, gendermainstreaming in disaster management is only recently exist along with the issuance of Perka BNPB No.13 Year 2014 on Gendermainstreaming in Disaster Management. There has been gap between national government policy on gendermainstreaming and the implementation of gendermainstreaming in disaster management bodies at provincial and local level due to the low commitment of local government and local legislative bodies in translating these policies into local government regulations (Perda) and standar operating procedure in implementing gendermainstreaming disaster management at the local level.

\section{RECOMMENDATION}

This study recommends the enhancement of local governments' capability and capacity in integrating gender in disaster management through routine and integrated capacity building on knowledge of gender, gender analysis and approaches and techniques in mainstreaming gender. The establishment of gender focal point in disaster management body of local government with adequate human and financial resources is urgent since itwill coordinate and stimulate local government to keep focus on diversity of needs and interests in disaster and conduct gendermainstreaming more effectively. Due to the intertwined structural, cultural and financial obstructions to engendering disaster management, the establishment of accountability mechanism in gendermainstreaming disaster management, the inclusions of gender specific guidelines and gender based evaluation indicators will ensure local government's commitment in gendermainstreaming disaster management.

\section{REFERENCES}

Abeysekera, S. (2006). Tsunami aftermath: Violations of women's human rights in Sri Lanka C. Akmatova (Ed.). accessed athttp://www.apwld.org/pdf/Tsunami s rilanka.pdf on 11 June 2016.

Anderson, M.B,. (1994). Understanding the Disaster-Development Continuum: Gender Analysis is the Essential Tool. In B. Walker (ed) Women and Emergencies. Oxford: Oxfam.

Alston, M. (2013) 'Introducing Gender and Climate Change: Research, Policy and Action', inAlston, M and K. Whittenbury (eds), Research, Action and Policy: Addressing the Gendered Impacts of Climate Change, Netherlands: Springer 
Ariyabandu, M., \& Wickramasinghe, M. (2003). Gender dimensions in disaster management.A guide for South Asia. Colombo, Sri Lanka: ITDG South Asia

Ashraf ,Mirza Ali , Md. Abul Kalam Azad. (2015). Gender Issues in Disaster: Understanding the Relationships of Vulnerability, Preparedness and Capacity. Environment and Ecology Research 3(5): 136-142 accessed at http://www.hrpub.orgon 13 June 2016

Banford, Alyssa and Froude, Cameron Kiely. (2015). Ecofeminism and Natural Disasters: Sri Lankan Women PostTsunami.Journal of International Women's Studies, 16(2), 170-187. Accessed at http://vc.bridgew.edu/jiws/vol16/iss2/ 11 on 10 June 2016.

Bradshaw, Sarah and Maureen Fordham. (2013). Women, Girls And Disasters A Review for DFID accessed at https://www.gov.uk/government/uploa ds/system/uploads/attachment data/file /236656/women-girls-disasters.pdf on 13 June 2016

. (2015). Gendered Rights in the Post-2015.Development and Disasters Agendas. IDS Bulletin, 46 ( 4 July 2015). Oxford - UK: John Wiley \& Sons Ltd.

Enarson, E. and Chakrabarti, PGD. (2009), Women, Gender, and Disaster, Sage Publication Privat Limited: India.

Fordham, M. (2004). Gendering Vulnerability Analysis: Towards a more Nuanced Approach. In G. Frerks, G. Bankoff and D. Hilhorst Mapping Vulnerability: Disasters, Development and People. London: Earthscan.

Greet, P. (1994) Making Good Policy into Good Practice. dalam B. Walker (Ed) Women and Emergencies. Oxford: Oxfam UK and Ireland.

Iqbal, M.Jawed, Haleema Sadia dan Naseem Baig. (2013). Gender Mainstreaming into Community Based Disaster Risk. European Scientific Journal November 2013, vol.9 (12). Accessed at http://eujournal.org/index.php/esj/artic le on 12 June 2016.
Hanani \& Kafa'ah. (2014). Perlawanan Perempuan di Pengungsian: Studi Keberadaan Perempuan di Pengungsian Gunung Sinabung, Kabupaten Karo, Sumaera Utara. Jurnal Ilmiah Kajian Gender. 4 (2).

Kelman, Ilan. (2015). Disaster Risk Governance for Pacific Island Communities.The Asia Pacific Journal Volume 13 | Issue 48 | Number 1.

Komnas Perempuan. (2012). Pencerabutan Sumber2 Kehidupan.Pemetaan Perempuan dan Pemiskinan dalam Kerangka HAM. Jakarta: Komnas Perempuan

Mileti, D. S. (1999). Disasters by design: A reassessment of natural hazards in the United States. Joseph Henry: Washington, DC.

Prabandari, Atin MA Randy W. Nandyatama, M. Sc. (2010). From Vulnerability to Resilience: The Role of Women in Building Disaster Resilient Community in the Aftermath of the 2010 Merapi Volcano Eruption. Research report.

Sendai Framework for Disaster Risk Reduction 2015-2030 diakses dari http://www.preventionweb.net/files/43 291 sendaiframeworkfordrren.pdf pada 13 Juni 2016

Siahaan, Asima Y. (2012). Decentralization and Women in Indonesia. Engendering Local Governance in North Sumatra. Lambert Academic Publishing: Germany. 2012.

UNISDR. (2014). Livingwith Risk. accessed at httpp://www.unisdr.org/eng/about_isdr /basic--docs/LwR2004/ch1_Section2.pdf>, on 11 June 2016.

UNI/SDR. (2012). International Day for Disaster Reduction Report, 'Women and Girls the Invisible Force of Resilience' accessed at <http://www.unisdr.org/2012/iddr/doc s/Final_ConceptNote Annexes.pdf>, on 11 June 2016.

Yumarni, Tri Dilanthi Amaratunga, Richard Haigh. (2015). The "State of DRR at the Local Level" A 2015 Report on the Patterns of Disaster Risk Reduction 
Actions at Local Level. Resource capability for local government in mainstreaming gender into disaster risk reduction: evidence from Indonesia. Accessed at https://www.unisdr.org/campaign/resi lientcities/assets/documents/privatepa ges/Resource $\% 20$ capability $\% 20$ for $\% 2$ olocal\%20government\%20in\%20main streaming, on 13 June 2016. 